\title{
PSCA Positive
}

National Cancer Institute

\section{Source}

National Cancer Institute. PSCA Positive. NCI Thesaurus. Code C159656.

An indication that PSCA expression has been detected in a sample. 